\title{
Effect of Color Composition in Work Space Against Job Performance
}

\author{
Rahmawan D. Prasetya \\ Department of Interior Design - Indonesia Institute of the Arts Yogyakarta, \\ Jl. Parangtritis KM 6,5, Yogyakarta 55118, Indonesia. Email: deprazz@yahoo.com
}

\begin{abstract}
This study investigates the influence of the physical environment on the work performance, regarding the composition of the colors used in the workspace. Thirty students of Academy of Management and Secretary were recruited through announcements on their campus and are grouped into three, namely the harmonious, disharmonic, and the control group. An experimental task that must be done is to copy the article to a computer for $2 \times 2$ hour, interspersed with rest for 1 hour. Results of their work in the form of typing is calculated based on the number of pages, rows, and the number of words with Word Count on Microsoft Word program. By using SPSS software version 17, the data were analyzed using Analysis of Variance Model. The results showed that there were significant differences in performance influenced by the composition of colors in the workspace based on the number of pages as indicator. But the other measurements based on the number of lines showed no significant difference. The measurement based on the number of words also showed no significant difference. With these results we can conclude that the work performance resulting in a workspace using harmonious color composition on the floor, walls, and windows has no significant difference with the performance produced in the work space with disharmonic and neutral color composition. Argumentation and future research suggestions are discussed.
\end{abstract}

Keywords: Work performance, color composition, workspace

\section{INTRODUCTION}

The existence of the workspace is an important factor in a firm institution. Digital age which obligates a company to have a website address does not reduce the significance of the existence of work and office space. Consumers, though familiar with the company through website, are still looking towards the physical existence of the company as a major requirement to gain trust in business. Physical presence was represented in the form of office spaces in the management of the company concerned.

Seeing the significance of influence of the office space, the company tried to put in order of priority in development. Leading interior designers are called, first-class building contractors deployed, many funds allocated to it, to obtain office space which can represent the company's image. Everything was done to get a positive image from consumers and potential consumers. 
The tendency shows that designing workspaces in a company has been in the ranks on the priority list of attention. On the other hand, the trend also shows that the company is preparing the office with a more aiming to focus on imaging issues. In fact, numerous studies have shown empirically that the workspace has a lot of influence psychologically for company employees. Room temperature, noise level, space organizing, arranging lay out, as well as the shape and position of furniture work are aspects of the study that has been shown to influence the psychological conditions of its inhabitants.

Similarly, the color of the workspace, Prasetya states that the composition of colors in the workspace is also the most important aspects that proved to affect a person's psychological aspect, such as work stress (Prasetya, 2007). This is in line with the statement of Naning Adiwoso (Adiwoso, 2005), a leading Interior Designer in Indonesia, who said that the presence of color applied to the work environment was necessary to compensate for the speed work in a variety of rapid change and dynamic. The colors chosen are certainly capable of providing psychological support for workers in carrying out their duties, which keep them away from negative effects such as fatigue, illness, and stress. But what often happens is that the selection of colors is only based on a mere design trend. As postmodern color trends that emerging today. Citing the opinion of Jean-Francois Lyotard, Kvale said that postmodern encourage a person to judge the beauty of something without any criterion of beauty itself. It prioritizes language games which are heterogeneous, inequality, instability, disunity, and conflict (Kvale, 2006). So is the postmodern-style design. Postmodern design has always tried to present the diversity of colors (polychromic), ornamentation, metaphors, symbolism, and a variety of conventions as said by Fuller, in Sumartono (Sumartono, 2004). In an extreme way it was even said that this post-modern design style provides an opportunity for the designer to confuse what is different and from different anywhere what was coming, then he can play around with all of it. It certainly has a psychological impact for someone when applied to the workspace.

The source of all of it was essentially the company's productivity. Employees who are in a healthy mental condition will surely maintain their productivity, and in turn will increase the productivity of the company. This study will focus on the investigation of the influence of the composition of colors applied in workspace towards the performance generated by the people who work in the space. Will the disharmonic color composition applied to the workspace affect job performance? Several studies have investigated the relationship between a person's working environments with their psychological condition. As performed by Evans and Johnson, which stated that there is a significant correlation between the noise in the workspace with job stress and job performance (Evan and Johnson, 2000). As part of the work space, workspace decoration or modification as the physical environment found able to reflect the existence of its inhabitants (Sommer, 1974; Sundstrom, 1986). Personalize workspace apparently affect the personality, uniqueness, and its status within the company, including its affiliates in a group (Heidments, 1994; Konar and Sundstrom, 1986; Wells, 2000).

What about the color of the workspace? A study conducted Prasetya found that the color composition applied to the workspace were affecting stress of someone worked in it (Prasetya, 2007). 


\section{Workspace Color Composition}

According to Raymond and Cunliffe, an office interior visible involves three elements, namely set (floor walls, ceilings), set dressing (furniture and accessories), and lighting (Raymond and Cunliffe, 2000). Architecturally, Ching asserts that space is a physical limit was the floor, walls, doors, windows, and ceilings (Ching, 1996). However, part of the space which has a primary color area, which can provide visual effects dominantly for users is the wall, floor, and window (Gilliat, 2001). These three elements are called the major areas of color. Therefore, those three elements manipulated in this study.

The use of color in workspace requires many considerations. One is the color composition arrangement consideration which is a major consideration in applying color to the workspace. Color composition in workspace is the application of color with a certain composition in workspace. The color application includes all elements of the room (floor, walls, and ceilings). Harmonic color composition is based on the color scheme which refers to the color wheel invented by Sir David Brewster (Levenson, 1980) and refined by Albert Munsell (Darmaprawira, 2002). which was then called the Munsell system (Figure 1). Some of the harmonic color composition were Monochromatic, Analogous, and some complementary composition (direct complement, triad complement, split complement, complement alternate, and tetrad) (Allen and Stimpson, 1994; Ching, 1996; Levenson, 1980).

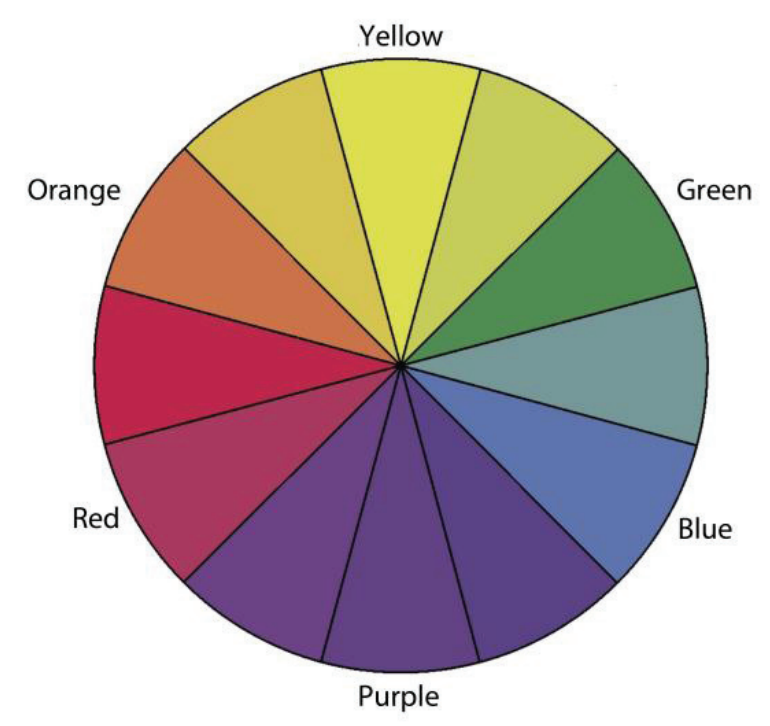

Figure 1. Standard Munsell Color Wheel

Disharmonic color composition is a composition that is not arranged by using the color scheme. Ching argues that whether or not a color match with other colors in the end depends on how and where the color is used, and how the color matched in color scheme (Ching, 1996). Durret and Trezone argues that the composition of colors that should be avoided in relation to human visual responses is the use of color in a pair of complementary color scheme (direct complement) and the composition settings that use more than four or seven colors (Bridger, 1995). 


\section{Job Performance}

Definition of work performance referred to as the performance or in English is called performance (Hornby and Cowie, 1987). Many experts are trying to define the term performance. Lawler says that the performance is a result that is achieved by the employee or job tasks efficiently and effectively (As'ad, 1991). Lawler \& Porter stated that the success of work performance is obtained by a person from the act or result concerned (As'ad, 1991). In a broader scope, Jewell \& Siegall stated that the achievement was a result of the extent to which members of the organization has been doing work in order to satisfy their organizations (Jewell and Siegall, 1990). Similar definitions expressed by Hasibuan which states that work performance is a result of one's work achieved in carrying out the tasks assigned to him based on skills, experience, sincerity, and time (Hasibuan, 1990). Thus the work performance is more of a person's level of success achieved to determine the extent of a person's achievement being measured or rated.

Zeitz says that the work performance is influenced by two main things, namely organizational factors (companies) and personal factors (Baron and Byrne, 2005). Organizational factors include reward systems, quality control, workload, values and interests, as well as the physical condition of the working environment. Among the organizational factors, the most important factor is the reward system, where these factors will be given in the form of salary, bonus, or promotion. In addition, a second organizational factor that is important is the quality of supervision (supervision quality), where a subordinate job satisfaction can be gained if their boss is more competent compared to them.

While personal factors cover characteristics of personality (personality trait), seniority, length of service, ability or skills related to the field of work and life satisfaction. For personal factor, which is also an important factor in work performance is a factor affecting the status and tenure. In general, people who have higher status jobs usually have showed good performance. The job status may give him an opportunity to obtain better working lives, so the opportunity to demonstrate the work performance is also getting bigger.

Companies always insist work performance on their employees. High employee performance will have an impact on increasing the productivity of the company and prevent employee turnover (in and out of the company). In addition, high work performance also impacted on corporate management establishment. Conversely, a low employee performance can reduce the level of quality and productivity, increased employee turnover rate, which in the end will impact on the company decline in revenue. This study aims to obtain empirical evidence which states the presence or absence of influence of the color composition in working space toward work performance, and empirical evidence stating that harmonious color composition can reduce work performance, and vice versa disharmonic color composition can improve work performance. So with this study, emerge a new understanding especially about the color composition of applications associated with the performance of user space. Thus, it is expected that aspects on employee performance will be used as an important consideration in setting workspace color composition within the scope of office interior design. 


\section{MATERIAL AND METHOD}

The study subjects involved in this experiment were 30 students from the secretary department of the Akademi Sekretaris dan Manajemen (Academy of Management and Secretary) that were recruited through advertisements on campus notice boards concerned, which contains an offer to participate in a study. The selection of subjects from the department secretary of ASMI is done on the basis that the duty of a secretary is dealing with correspondence and assumed each participant is able to operate Microsoft Word program. Characteristics of participants are women, 20-30 years old, and have an ability to operate Microsoft Word Program. Women participant had been taken because Stoney, et.al. said that there is sex difference in psychological response of stressor, women more sensitive on stressor than men (Evans and Johnson, 2000). Methods of recruitment and selection of the subject refers to the method used by Prasetya (Prasetya, 2007). Each participant was given honorarium as compensation for their participation. All participants declared in a state of normal vision through color blind test at the beginning of the experiment. Participants who were 30 were divided into 2 treatment groups and 1 control group (each 10 people per group). This experiment is planned to last for 4 hours. At the beginning of the experimental session, as a cover story, the subjects were told that the experiment was conducted to determine the effect of computer furniture (tables and chairs) to the satisfaction and comfort in work of its users.

Color room is manipulated, especially the color on the walls, floor (carpet), and windows (curtains). All three are major areas of color (Gilliat, 2001). The existing furniture is colored light gray (table and chairs) and working equipment such as computers and keyboards are white. In this experiment, first treatment condition is color work room with harmonious composition, using the primary colors in the Munsell color scheme, which is blue. The color determination is based on the results of experiments conducted by Hanna \& Remington, which states that the shape and color of an object was represented separately in memory recall recall (Hanna and Remington, 1996). Thus, the color on the workspace can affect the subject, because the overall composition that forms a certain atmosphere, not because of the colors associated with the memory of the subject. The blue color will not be associated with a calm sea by the subjects. In addition, Joy Fisher revealed that the bluish-gray color is the only color without the "after image" left in our brain, light gray bluish produce great background for serious thinking. Overall efficiency can be improved by using a blue sky and blue sea color (Fisher, 2005).

In the second treatment condition/workspace with non-harmonious color composition it is used more than 7 different colors (Bridger, 1995), with red as the dominant color, while other colors applied are green, blue, yellow, orange, brown, purple, beige, which in composition arranging is irregular and purposely not considering aesthetic aspects. As a condition control, the white dominant color is used in the other room. Experiments conducted in a room that measures $9 \times 9$ feet (Figure 2).

Acclimatization and lighting conditions each room for the 3 experiment conditions (control condition, treatment 1 and treatment 2 ) is carefully controlled by using the tools Anemometer, Lux meter/light meter, and Sound-level meter. 
All of participants were asked to copy writing with Microsoft Word on a computer program that has been provided from an article that has not relevant with this experiment at all (about aerospace), as in the experiments on the noise made by Evans and Johnson (Evans and Johnson, 2000) and Prasetya (Prasetya, 2007). Furthermore, participants were asked to work with a relaxed attitude, as their work habits, and explicitly told that no one is watching over their work. This is done to avoid the impact of the supervision/monitoring on employee performance (Larson and Callahan, 1990), which feared could affect the outcome of this experiment. Having lasted for 4 hours, the experimental session ended. Subjects were asked to save their work on each computer.

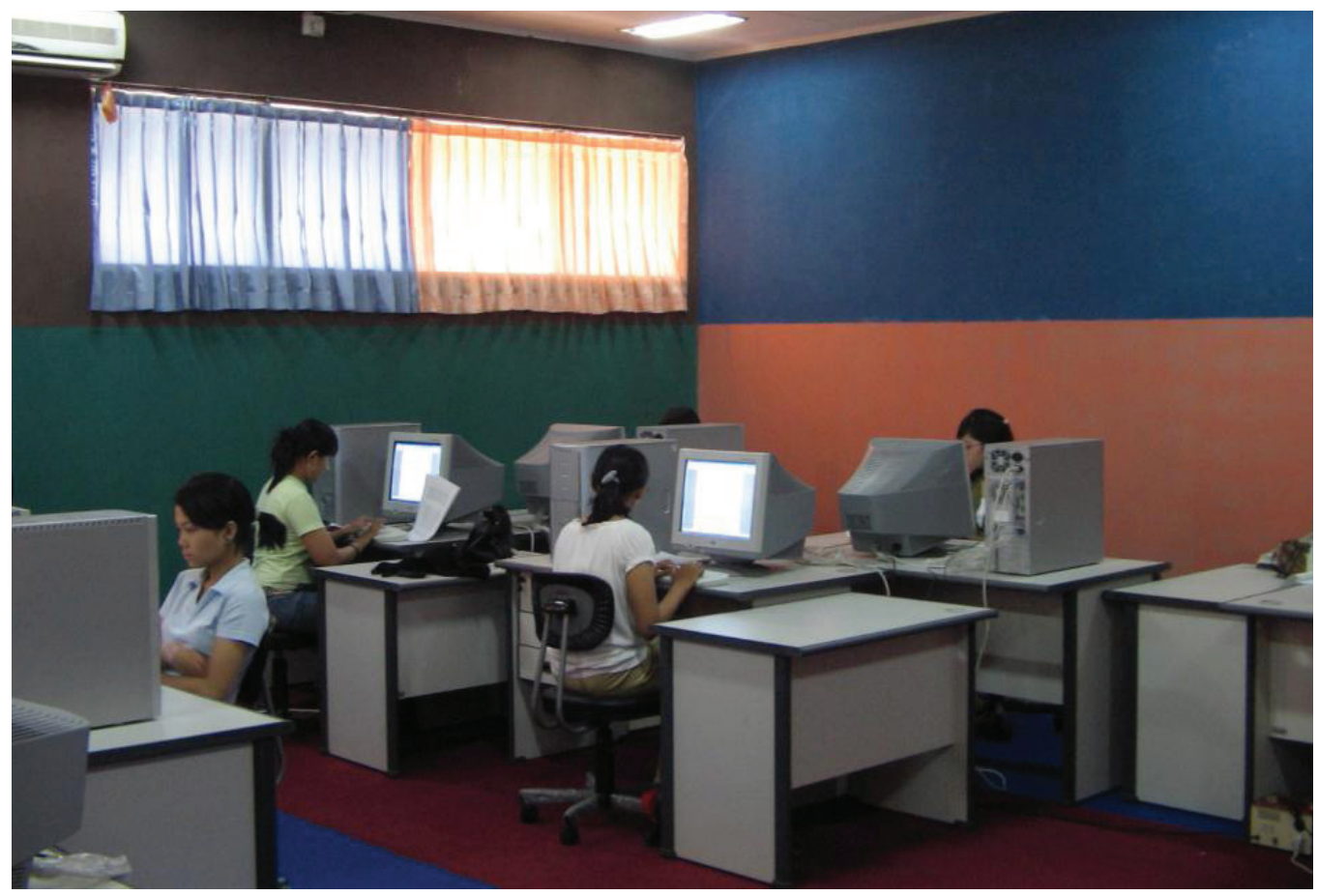

Figure 2. Work place setting.

Performance as the dependent variable is measured through achievement generated during the experiment. Because the experimental task performed was typing using Microsoft Word software, then the resulting performance can be analyzed through the word count facility that can reveal the number of pages, number of words, number of characters (with and without spaces), number of paragraphs, and the number of lines. Correlation coefficient of number of pages, number of lines and number of words with their score each of their total are significant statically. So, it can be conclude that word count facility in Microsoft Word have valid instrument. Mean of word count is 2702.37, variance is 425630.52 , and with a standard deviation are 652.40 . The result of reliability test showed value of alpha 0.349 . Because of the minimal value of alpha is 0.30 , so, it can be conclude that all of item in word count are reliable and can used to measure work performance.

Measurements were performed 2 times as pre-test and post-test. At pre-test, the subject has not produced any, so is considered 0 (zero). While the post-test was conducted 
after the session is completed experiment by looking for a set of each subject by using word count on Microsoft Word program.

Result data were analyzed by ANOVA using SPSS, statistical program assistance. ANOVA (Analysis of Variance) is a procedure that tries to analyze the variation of response or treatment, and try to implement this portion of the variance in each group of independent variables. This technique simultaneously compares multiple variables that can minimize the possibility of error. The purpose of this variance analysis is to find the independent variables in the research and determine how they interact and affect treatment or response response (Santosa and Ashari, 2005). The design of this analysis is in accordance with the purpose of testing the hypothesis mentioned above. Because this experiment consisted of 3 groups with 2 replicates observations, the design of 2-Factor ANOVA was used to analyze the data obtained during the experiment. The effect of independent variables on the dependent can be seen from the value of $t$ on the results of analysis of variance calculations. To determine the effect of two independent variables and one control variable on the dependent variable together can be seen from the value of $\mathrm{F}$ obtained.

\section{RESULTS AND DISCUSSION}

Based on the mean number of pages produced, the control group showed the highest rate, which is 9.10 with a standard deviation of 2.424, followed by group Harmonious 8.70 with a standard deviation of 1.829 , and the group Disharmonic 6.90 with a standard deviation of 1.287 (see Figure 3).

Results of calculation of variance with Levene's test of homogeneity of Statistics showed a value of 0.945 with a significance of 0.401 . Because the significance value is greater than the level of trust, then the decision is to accept $\mathrm{H}_{0}$. It means that the variance of the number of pages is the same in all three groups.

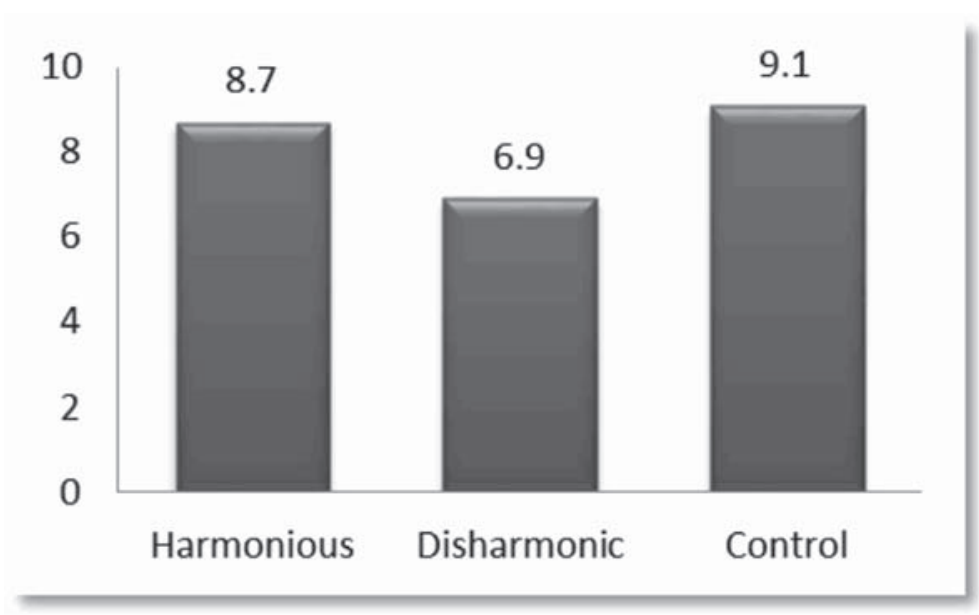

Figure 3. Graphic of the average of pages.

With these results, the ANOVA test using the F-test can be done. The result shows calculated $F$ value of 3.788 with a significance value of 0.035 . With these results, it can be taken a decision to reject $\mathrm{H} 0$ because the calculated $\mathrm{F}$ value is greater than the value of $\mathrm{F}$ table. With these results, it can be taken a decision to reject $\mathrm{H} 0$ because the 
calculated $\mathrm{F}$ value is greater than the value of $\mathrm{F}$ table. Thus, the conclusions were that the performance rated based on the average number of pages for workspaces with Harmonic color composition, Disharmonic, and Neutral (control) was significantly different.

In the analysis based on the number of lines, the mean generated by the control group also showed the highest rate, which is 378.80 with a standard deviation of 109.584, followed by group Harmonious 363.30 with a standard deviation of 110.154 , and the last group Disharmonic 301.20 with a standard deviation of 47.960 (see Figure 4).

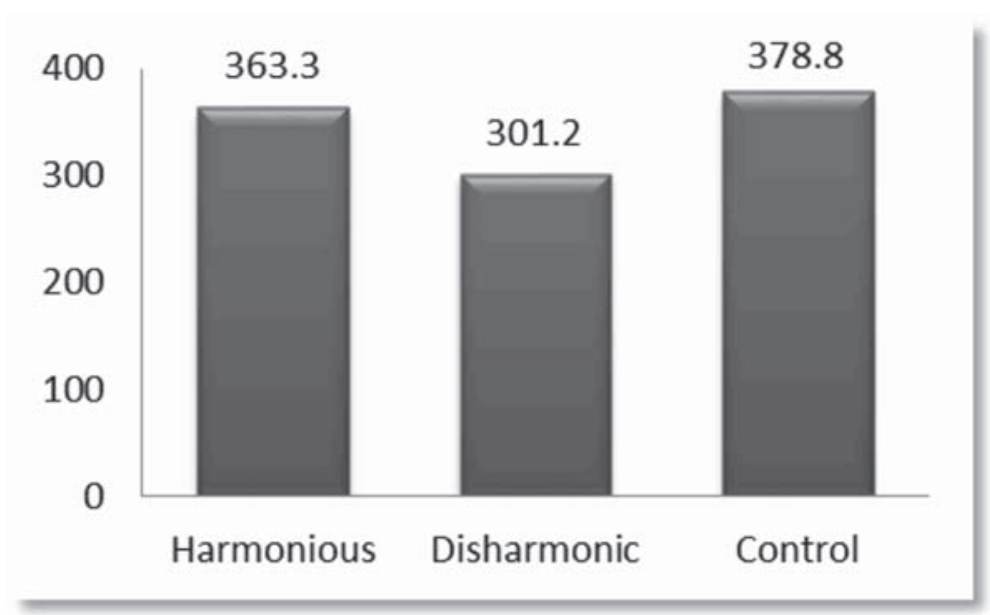

Figure 4. Graphic of the average of lines.

Through calculations with Levene Statistics, test results of variance homogeneity showed a value of 1.716 with significance 0.199 . Because the significance value is greater than the level of trust, then the decision is to accept $\mathrm{H}_{0}$. It means that the variances of the number of lines generated by the typing from the three groups are the same. Therefore, ANOVA test using the $\mathrm{F}$ test can be done. The calculation of the Analysis of Variance (ANOVA) showed a calculated F value of 1.913 with a significance value of 0.167 . It means that no significant difference among the three of group experiment.

Analysis for the performance based on the number of words typed showed same results with the performance based on the number of rows. The mean of the performance based on the number of words for the control group was 2346.9 with a standard deviation of 606.378 , followed by Harmonic at 2429.6 with a standard deviation of 703.749 , and the group Disharmonic of 2262.6 with a standard deviation of 378.527 (see Figure 5).

The results of the test of homogeneity of variance with Levene Statistics showed a value of 0.677 with a significance of 0.517 ( $>0.05$, not significant). These results are used as the basis of decision making to accept $\mathrm{H}_{0}$. This means that the variance of the number of words generated from the control group, Harmonious, and Disharmonic are the same. Therefore, ANOVA test using the F test can be carried out. ANOVA test on the number of the word itself shows calculated $\mathrm{F}$ value of 0.208 with a significance of 0.814 ( $>0.05$, not significant). With results it can be taken a decision to accept $\mathrm{H}_{0}$. 
It means that the resulting performance in the work space with harmonious color composition, disharmonic, and neutral (white and gray) are not significantly different.

Performance measurement based on the number of pages showed result that there is a significant difference between the three experimental groups, Harmonious,

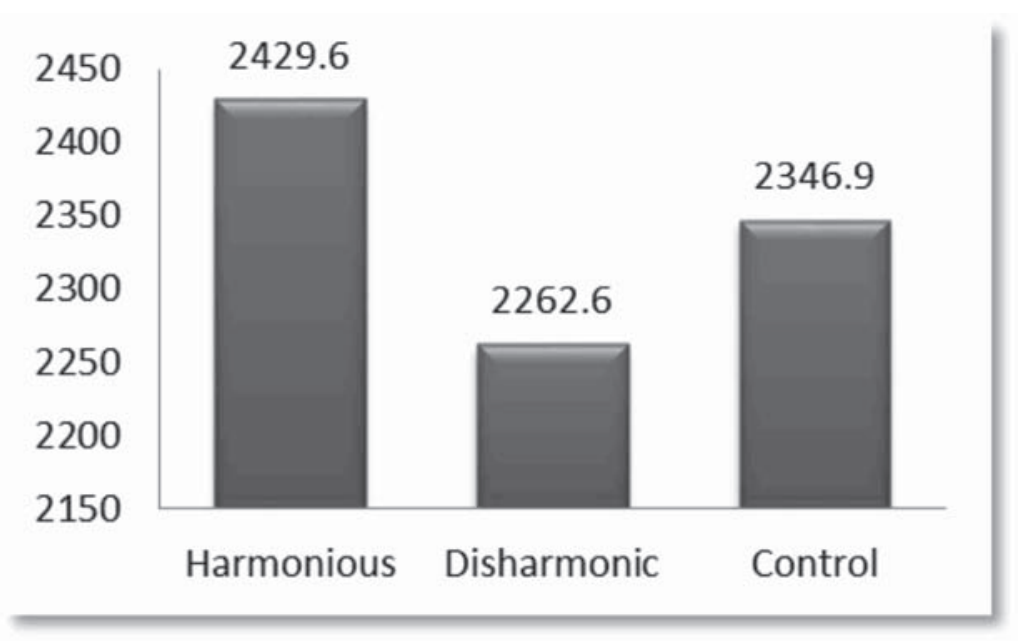

Figure 5. Graphic of the average of words.

Disharmonic, and Control. While based on the number of lines and words, the results of measurement and analysis showed no significant difference among the three treatment groups. It can occur because of differences in sensitivity between the three instruments. The fundamental difference of these three indicators is that the number of lines and words have more sensitively measure the results than which are achieved compared to the number of pages. Thus it can be said that when performance is measured by using a less sensitive measuring instrument results obtained are significant, meaning that there are differences between the three experimental groups. However, when measured by a more sensitive measuring instrument, the results obtained are not significant, which means there is no difference between the three experimental groups. However, when measured by a more sensitive measuring instrument, the results obtained are not significant, which means there is no difference between the three experimental groups.

\section{CONCLUSION}

The absences of significant differences between the three experimental groups are different from the results of research conducted by Prasetya. His research that investigates the influence of workspace color composition on work stress resulted in the finding that the composition of neutral colors (white and gray) in the workspace tends to reduce job stress. While harmonious color composition in workspace tends to maintain, not increase but neither reduce job stress. Instead disharmonic color composition in workspace increases job stress. Thus, this study also produced findings that job stress does not always cause a decrease in job performance. The conclusion that there is no difference in the job performance generated by the working space with harmonic color composition, disharmonic, and neutral is not in line with 
research by Prasetya (2007). Nevertheless, there are shortcomings in the study that would otherwise need to be used as consideration in similar studies in the future. Performance measurement using a word count should be accompanied by a counting on the typing error performed. Thus it will be more likely to indicate the actual performance results.

\section{REFERENCES}

Adiwoso, N. (2005). Color forecast 2004-2005. Paper presented in Seminar of Design and Color Trend 2005, Pebruari 2005, Yogyakarta.

Allen, P. S. \& Stimpson, M. E. (1994). Beginnings of interior environment. New Jersey: Macmillan College Publishing Company Inc.

As'ad, M. (1991). Psikologi industri. Yogyakarta: Liberty.

Baron, R.A. \& Byrne, D. (2005). Psikologi Sosial. Jakarta: Penerbit Erlangga.

Bridger, R.S. (1995). Introduction to ergonomics. Singapore: McGraw-Hill Inc.

Ching, F. D. K. (1996). Interior design illustrated. New York: Van Nostrand Reinhold Publishing Inc.

Darmaprawira, S. (2002). Warna dan kreativitas penggunaannya. Bandung: Penerbit ITB.

Evans, G. W., \& Johnson, D. (2000). Stres and open-office noise. Journal of Applied Psychology, 85, 779-783.

Fisher, J.J. (2005). Design psychology. California: Ted Blake Publisher.

Gilliat, M. (2001). Interior design course. London: Conran Octopus Limited.

Hanna, A. \& Remington, R. (1996). The representation of color and form in long-term memory. Memory \& Cognition, 24, 322-330.

Hasibuan, M.S.P. (1990). Manajemen sumber daya manusia: dasar kunci keberhasilan. Jakarta: CV Haji Mas Agung.

Heidments, M. (1994). The phenomenon of personalization of the environment: A theoritical analysis. Journal of Applied Communication, 21, 189-210.

Hornby, A. S., \& Cowie, A. P. (1987). Oxford advanced learner's dictionary of current English. Oxford: Oxford University Press.

Jewell \& Siegall, M. (1990). Psikologi industrilorganisasi modern. Jakarta: Penerbit Arcan.

Konar, E. \& Sundstrom, E. (1986). Status demarcation and office design. In J.D. Wineman (eds.), Behavioral issues in office design. New York: Van Nostrand Reinhold

Kvale, S. (2006). Psikologi \& posmodernisme. Yogyakarta: Pustaka Pelajar.

Larson, J.R. \& Callahan, C. (1990). Performance monitoring: How it affects work productivity. Journal of Applied Psychology, 75, 530-538.

Levenson, H. (1980). Creating an interior. London: Prentice Hall International Inc.

Raymond, S. \& Cunliffe, R. (2000). Tomorrow's office: Creating effective and humane interiors. London: E \& FN Spon.

Santosa, P.B. \& Ashari. (2005). Analisis statistik dengan Microsoft Excel dan SPSS. Yogyakarta: Penerbit ANDI.

Sommer, R. (1974). Tight spaces: Hard architecture and how to humanize it. New Jersey: Prentice Hall.

Sumartono. (2004). Merenungkan kembali gerakan anti-desain. Jurnal Seni Rupa dan Desain, 01, 37-43.

Sundstrom, E. (1986). Work places: The psychology of the physical environment in office and factories. New York: Cambridge University Press.

Wells, M. (2000). Office clutter or meaningful personal displays: The role of office personalization in employee and organization well-being. Journal of Environmental Psychology, 20, 239-255. 